\title{
Taxes and dividend policy under alternative tax regimes
}

\author{
Kerry Pattenden ${ }^{a}$, Garry Twite ${ }^{\mathrm{b}, *}$ \\ a Discipline of Finance, School of Business and Economics, University of Sydney, Sydney, NSW 2006, Australia \\ ${ }^{\mathrm{b}}$ School of Finance and Applied Statistics, Australian National University, Canberra, ACT, 0200, Australia
}

Received 23 November 2004; received in revised form 19 September 2007; accepted 20 September 2007

Available online 29 September 2007

\begin{abstract}
This paper examines changes in corporate dividend policy around the introduction of a dividend imputation tax system. This represented a significant change to the Australian tax framework and allows us to test the effect of differential taxation on corporate dividend policy. Consistent with the tax preference for the distribution of dividends, we find dividend initiations, all dividend payout measures and dividend reinvestment plans increased with the introduction of dividend imputation. Similarly we find that gross dividend payouts are more volatile under dividend imputation. Finally, we find that the increase in dividend payout and initiations differs across firms. In particular, we find that the higher the level of available franking tax credits the higher the firm's gross dividend payout and the more likely the firm is to initiate a dividend.
\end{abstract}

(C) 2007 Elsevier B.V. All rights reserved.

JEL classifications: $\mathrm{G} 35 ; \mathrm{H} 25$

Keywords: Dividend policy; Taxes; Dividend imputation

\section{Introduction}

How firms set their dividend policy has been the focus of extensive research since the seminal work of Miller and Modigliani (1961). They showed that, in a frictionless capital market, a firm's dividend policy will not affect its value. Miller and Scholes (1978) show that in a world where both dividend income and capital gains are taxed at investor levels, the preference for dividends or capital gains depends upon relative tax rules governing possible tax arbitrage. Despite this, even though for many shareholders dividends are taxed more heavily than capital gains firms have paid out a significant proportion of their earnings as dividends. This propensity of firms to pay dividends has been labelled the "dividend puzzle", ${ }^{1}$ in part reflecting the lack of a substantive empirical explanation for firm and investor behaviour.

\footnotetext{
Th This paper has benefited from the useful comments and suggestions provided by Joseph Fan, Doug Foster, Ning Gong, Jay Hartzell, Jeffry Netter, Tom Smith, Sheridan Titman, Roberto Wessels, seminar participants at the University of Sydney and an anonymous referee. We wish to thanks Nick Dowsley, Karina Fung, Michael O'Brien and Kate Willcock for assistance in collecting dividend payment data.

* Corresponding author. Tel.: +6126125 0729; fax: +61261250087.

E-mail addresses: kerryp@econ.usyd.edu.au (K. Pattenden), garry.twite@anu.edu.au (G. Twite).

${ }^{1}$ Black (1976).
} 
This paper examines the changes in corporate dividend policy around the introduction of a dividend imputation tax system. ${ }^{2}$ The use of Australian data allows a study of dividend policy under two alternative tax systems with different distribution incentives across both tax regimes, namely, to retain (prior to the tax change) or distribute (post the introduction of dividend imputation) dividends. The results of the study give insight into the type and power of dividend responses to significant changes in taxation rulings designed to impact cash disbursements to investors.

The introduction of dividend imputation in Australia in 1987 offers an experimental setting for testing managerial responses to a tax ruling that significantly changes the value of dividends vis a vis the retention of earnings and the issuance of debt. Twite (2001) demonstrates that the introduction of dividend imputation created a differential impact on firm financing choices and investor preferences resulting in a shift within the firm away from debt and retained earnings to new equity. One of the characteristics of this financing move is the increased use of dividend reinvestment plans (DRP) and script dividends, whereby investors get the desired tax benefit from the distribution of tax credits and managers retain capital within the firm for future investment needs.

Studies in Canada (Khoury and Smith, 1977) and the United Kingdom (Poterba and Summers, 1984) which both introduced dividend imputation tax regimes demonstrate similar outcomes for aggregate dividend policy. These are in contrast to U.S. studies (Michaely, 1991; Smith and Watts, 1992) around the Tax Reform Act of 1986 that report no significant changes in dividend payouts. The conflicting conclusions between the U.S. and imputation regimes suggest that capturing tax effects is difficult and major changes to the tax structure such as a dividend imputation system are required to generate significant observable changes in managerial behaviour. The present study reaffirms the earlier findings and extends our understanding of tax driven dividend behaviors. This is done through examination and documentation of the specific tax changes in our data and their impact on firm dividend policy.

We make use of a unique feature of the Australian dividend imputation tax system, namely, varying levels of tax credit distributed with dividends, to examine differences in firm responses to tax changes. If investors value tax credits there is a tax incentive to distribute dividends, increasing dividend payouts. At the firm level, the magnitude of this tax incentive, and hence, the increase in dividend payout, will be a function of the amount of tax credits available for distribution.

Unlike previous papers we test investor demand for the distribution of tax credits across all forms of dividend payments, and hence, we measure gross dividend payout ratios as the sum of regular cash dividends, regular script dividends, bonus share plans, special cash dividends, special script dividends and share repurchases. ${ }^{3}$ In order to capture the trade-off between managerial financing incentives and investor demand for tax credits we measure net dividend payout ratios as gross dividends net of dividend reinvestment plans, share repurchases and new shares issued.

Over the sample period 1982 to 1997, we find that gross, regular and net dividend payout ratios and dividend initiations ${ }^{4}$ increased subsequent to the introduction of dividend imputation, consistent with the demand for the distribution of tax credits via dividend payments. In addition, we find that gross dividend payouts are more volatile under dividend imputation. Consistent with Chan et al. (1995) we find that the use of bonus share and dividend reinvestment plans also increased subsequent to the introduction of dividend imputation. Interestingly, even after allowing for new equity issues, the introduction of dividend imputation raises dividend payouts. ${ }^{5}$

Although many of our findings are consistent with the existing literature, we report a number of new between firm regularities. We find that the higher the level of franking tax credit available the higher the firm's gross dividend payout and the more likely the firm is to initiate a dividend. In particular, we find that firms with a high effective Australian corporate tax rate or a high proportion of income available as franked dividends have higher gross dividend payouts. Likewise, firms with a high proportion of income available as franked dividends are more likely to initiate a dividend. In general, unlike many prior studies we find that firms distribute cash flows with franking credits attached to investors by all means available in order to satisfy the investor demand for the tax offset.

\footnotetext{
${ }^{2}$ Dividend imputation systems are also in place in a number of countries, including Canada, France, Germany, Italy, New Zealand and United Kingdom. The proportion of corporate tax available as a tax credit under these imputation systems varies from country to country. Only in Australia, Germany, Italy and New Zealand is the full amount of the corporate tax paid distributed as a tax credit.

${ }^{3}$ Grullon and Michaely (2002) adopting a similar measure of the gross dividend payout ratio to examine the substitution of share repurchases for cash dividend by U.S. firms.

${ }^{4}$ The potential impact of the introduction of a dividend imputation system on the frequency of dividend initiations was pointed out to the authors by an anonymous referee.

5 The increase in gross dividend payout ratio contrasts with Grullon and Michaely (2002) who find that over a similar time period, the gross dividend payout ratio has for a sample of U.S. firms remained relatively constant, albeit under a classical tax system.
} 
The paper is organized as follows. Section 2 describes the Australian taxation system during the period of this study and examines the existence of tax induced preferences under dividend imputation. Section 3 examines the influence of tax preferences on dividend policy under alternative tax regimes. Section 4 describes the sample. Section 5 presents the empirical results and Section 6 draws some conclusions.

\section{The Australian taxation system and investor preferences}

During the sample period 1982 to 1997 , Australia changed from a classical tax system to a dividend imputation system. On 1 July 1987 a dividend imputation system was introduced. Prior to 1 July 1987, a classical tax system existed in Australia, with dividend payments taxed at both the corporate and personal levels. ${ }^{6}$

\subsection{Dividend imputation}

Australia's dividend imputation system applies to dividends paid by Australian resident firms to resident individual shareholders and a limited class of other resident shareholders, including Australian pension funds. Australian corporate tax paid by firms is allocated to shareholders by way of imputation credits. Imputation credits are included in the taxable income of eligible shareholders who are then entitled to a tax rebate equal to the tax credit included in their dividend. Tax credits not used by the investor in the current year are lost, there is no carry forward of the tax credits or cash refunds. ${ }^{7}$ All inter-firm dividends are exempt from corporate tax in the hands of the receiving firm; the imputation tax credits are preserved and can be paid to the receiving firm's shareholders.

Dividends paid from earnings that have been taxed at the full Australian corporate tax rate are termed franked dividends and include an imputation tax credit, whereas, dividends paid from earnings on which no Australian corporate tax has been paid are termed unfranked dividends and do not include an imputation tax credit. Dividends franked between zero and $100 \%$ are a mixture of franked and unfranked dividends and are termed partially franked dividends.

In general, while corporations face the same statutory tax rate they can have different effective tax rates and levels of franking. This arise because (i) depreciation expenses and investment allowances are tax deductible and (ii) any foreign income on which corporate tax has been paid in the foreign country is not part of the imputation system. Hence, it is the level of Australian corporate tax paid that determines the level of franking of dividends, where differences in effective tax rates across firms imply varying levels of tax credits available for distribution with dividends.

\subsection{Tax induced preferences}

The impact of taxes on dividend policy depends on the relative taxation of dividends and capital gains. In general, there will be a preference for dividends whenever the effective personal tax on capital gains is greater than the effective personal tax on dividend income and vice versa. ${ }^{8}$ Table 1 describes the two variant tax regimes over the sample period 1982-1997. The first represents a classical tax system with double taxation of dividends and tax exempt pension funds. The second represents a change from a classical tax system to a dividend imputation system, with tax credits flowing from the issuing company to the investor and taxable pension funds.

Table 1 documents investor tax rates on dividend income and capital gains for the highest personal taxpayer, corporate investors and pension funds; assuming that all taxes are paid at the statutory rate and capital gains are realized. From these tax rates, we compute the after tax value of a dollar of pre-Australian corporate tax earnings as it flows to an investor through different routes: dividends or capital gains. Under dividend imputation, the first value applies to franked dividends and the second value to unfranked dividends.

\footnotetext{
${ }^{6}$ While the introduction of a dividend imputation system represents the focus of this study, several other changes to the Australian taxation system occurred over the sample period 1982 to 1997. A capital gains tax was introduced on 19 September 1985. On 1 July 1988 pension funds, which were previously tax-exempt, were subject to a $15 \%$ tax rate. The taxation of pension funds is important because of the introduction in Australia on 1 October 1992 of compulsory pension plans for all income earners thereby significantly increasing the role of pension funds as a major investor in the Australian equity market. Further, over the sample period, both the top personal tax rate and the corporate tax rate were reduced.

${ }^{7}$ This was the case during the period of this study. From July 2000 Australian taxpayers are eligible for a rebate of unused tax credits on dividends.

${ }^{8}$ This recognizes that investors are able to adjust the timing of capital gains and losses.
} 
Table 1

Summary of Australian tax systems: 1982 to 1997

\begin{tabular}{lcc}
\hline & Classical tax system & Dividend imputation tax system \\
\hline Statutory tax rates & & 36.00 \\
Corporate tax rate & 46.00 & 47.00 \\
Individual investor & 60.00 & 56.00 \\
$\quad$ Dividend (\%) & 0.00 & 0.00 \\
$\quad$ Imputation tax credit (\%) & & 56.00 \\
Corporate investor & 0.00 & 15.00 \\
$\quad$ Dividend (\%) & 0.00 & 56.00 \\
$\quad$ Imputation tax credit (\%) & 0.00 & $0.53 / 0.53$ \\
Pension Funds & 0.00 & $1.00 / 1.00$ \\
$\quad$ Dividend (\%) & & $0.85 / 0.85$ \\
$\quad$ Imputation tax credit (\%) & 0.22 & $0.34 / 0.53$ \\
Dividend payment (\$) & 0.54 & $0.40 / 0.64$ \\
$\quad$ Individual investor (\$) & 0.54 & $0.54 / 0.85$ \\
$\quad$ Corporate Investor (\$) & & \\
Pension fund (\$) & 0.22 & \\
$\quad$ Individual investor (\$) & 0.29 & \\
$\quad$ Corporate Investor (\$) & 0.54 & \\
$\quad$ Pension fund (\$) & &
\end{tabular}

Source: Price Waterhouse, "Doing Business in Australia", various issues.

The table presents the after-all tax value of a dollar of pre-Australian corporate tax earnings as it flows to an investor through dividends. The investor groups identified are the top personal tax rate, corporate investors and pension funds. Under dividend imputation, the first value applies to franked dividends and the second value to unfranked dividends. Franked dividends are paid from earnings have been taxed at the full Australian corporate tax and include an imputation tax credit. Unfranked dividends are paid from earnings on which no Australian corporate tax has been paid and do not include an imputation tax credit. When distributed via dividends it is computed as earnings $\times(1-$ corporate tax rate $)(1+$ imputation tax credit $)(1-$ dividend tax rate). When retained it is computed as earnings $\times(1$ - corporate tax rate $)(1-$ capital gains tax rate $)$. The imputation tax credit is dividend $\times$ corporate tax rate/(1-corporate tax rate). We assume that all taxes are paid at the statutory rate and capital gains.

Assuming that any one class of investors can receive both dividends and capital gains, we use the after tax value of a dollar of dividends and capital gains income to infer the existence of tax preferences for different distribution methods.

From Table 1 we infer that under a classical tax system, corporate investors prefer dividend payments over capital gains, while individuals and pension funds are indifferent to dividends. ${ }^{9}$

The change in tax regime has been associated with changes in tax rates for all investor groups. These changes reduced the gap between firm and investor tax rates and thereby increased the value to the investor of the tax credit. The result of these changes is that with the introduction of dividend imputation all investor groups prefer the distribution of franked dividends since this is the only way they can access the associated tax credit. ${ }^{10}$ However the preference for distribution of unfranked dividends will remain, as it is under a classical tax system, a function of the trade off between dividend and capital gains investor tax rates.

\section{Taxes and dividend payout}

The tax preference for the distribution of franked dividends following the introduction of a dividend imputation tax system suggests that regular dividend payments by all firms will increase. Although most dividends are paid in the form of regular semi-annual cash payments, dividends can also be paid as share repurchases or in a non-cash form as script dividends. The imputation tax system does not discriminate between the forms of the dividend payment; hence a script dividend can be either franked or unfranked. Further, firms are not restricted to regular semi-annual dividend payments; they can declare a special (or irregular) dividend. Like regular dividends, special dividends can be paid in the form of

\footnotetext{
${ }^{9}$ Since only realized capital gains and losses are taxed, the "effective" capital gains tax rate is less than the statutory tax rate on dividend payments implying a tax preference for capital gains over dividend payments.

${ }^{10}$ Pension funds, as a result of the introduction of compulsory pension plan contributions have become the largest investor grouping in the Australian market. The decision to change their taxation status meant that they were able to access imputation tax credits.
} 
cash, shares or an off-market share repurchase. Off-market share repurchases ${ }^{11}$ may include a dividend component, in addition to the capital component, where the dividend component may be a franked or unfranked. We focus only on those off-market share repurchases that include a dividend component. We define the firm's gross dividend payment to be the sum of regular cash dividends, regular script dividends, bonus share plans, ${ }^{12}$ special cash dividends, special script dividends and off-market share repurchases. Therefore, we hypothesise that, ceteris paribus, both regular and gross dividend payout ${ }^{13}$ will increase for all firms following the introduction of dividend imputation. ${ }^{14}$

Using a sample of dividend-paying firms, we analyse the behaviour of dividend policy around the introduction of dividend imputation using the following regression equation:

$$
\mathrm{DP}_{i t}=\hat{\beta}_{1} D+\hat{\beta}_{2} W_{i j t}+\varepsilon_{i t}
$$

Where the dependent variable $\left(\mathrm{DP}_{i t}\right)$, the measure of the dividend payout ${ }^{15}$ for firm $i$ is:

(i) gross dividend payout in period $t$, [ $\left.\frac{\text { gross dividend payment }}{\text { net income }}\right]$,

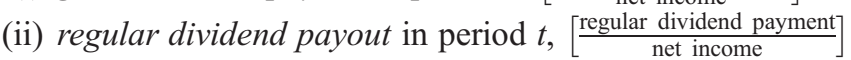

We use a dummy variable to examine the changes in dividend policy around the introduction of the dividend imputation tax system. $D$ is the imputation dummy taking a value of one under an imputation system and zero otherwise.

$W_{i j t}$ is the $n \times j$ matrix of firm characteristics. We proxy these firm characteristics to control for non-tax effects that if ignored would create a missing variable problem.

While the existing empirical evidence on dividend policy under a classical tax system ${ }^{16}$ suggests that managers smooth dividends relative to earnings, we conjecture that this will not be the case under a dividend imputation system. As the level of Australian corporate tax rate paid determines the level of franked dividends, volatility in pre-tax income and corporate tax paid implies volatility in the level of imputation tax credits available for distribution and hence franked dividends. Likewise, volatility in the level of franked dividends suggests that the volatility of gross dividend payout will increase. Therefore, we hypothesise that, ceteris paribus, there will be an increase in the volatility of the gross dividend payout subsequent to the introduction of dividend imputation.

The volatility of gross dividend payout around the introduction of dividend imputation is analysed using the following regression equation: ${ }^{17}$

$$
\operatorname{GrossDP}_{i t}=\hat{\beta}_{1} \text { Profit }_{i t}+\hat{\beta}_{2} \operatorname{GrossDP}_{i t-1}+\hat{\beta}_{3} D \times \operatorname{GrossDP}_{i t-1}+\varepsilon_{i t}
$$

Where the dependent variable $\left(\mathrm{GrossDP}_{i t}\right)$, is the gross dividend payout for firm $i$ in period $t$, Profit ${ }_{i t}$ is firm $i$ 's profitability in period $t,[$ net income $]$ total assets $]$, and $\left(\mathrm{GrossDP}_{i t-1}\right)$, is the gross dividend payout for firm $i$ lagged one period. We include an interaction effect between the imputation dummy variable, $D$, and firm $i$ 's lagged gross dividend payout

\footnotetext{
${ }^{11}$ Shares can be repurchased via an on-market or off-market offer, and by an offer to all shareholders or a particular group of shareholders. The tax treatment of on-market and off-market offers differs. With on-market offers the total purchase price is subject to tax, just as if the share had been sold by the shareholder.

${ }^{12}$ Under a bonus share plan shareholders elect to receive a bonus share (script) instead of a cash dividend.

${ }^{13}$ While franked dividends include a tax credit, the dollar value of the tax credit is not included in the calculation of our measures of dividend payout.

${ }^{14}$ Dividend distribution may be measured in terms of dividend payout, or dividend yield [gross dividend payment/market value of ordinary shares]. Since the present paper is focused on managerial initiated changes; the analysis measures dividend distribution using dividend payout. Dividend yield by virtue of its construction as a function of market capitalization can fluctuate as a result of market movements and therefore may generate measurement noise around the interactions being examined.

${ }^{15}$ Our results may be influenced by our choice of scaling variable, changes in the reporting of net income over the sample period can result in a change in our dependent variable unrelated to changes in dividend payments. In order to mitigate this potential effect, we alternatively scaled dividend payment by total assets. Our results are robust to this change in scaling.

${ }^{16}$ See Partington (1984) in the context of Australian companies under a classical tax system, Aivazian et al, (2003a) in the context of a sample of developed and developing countries and Allen and Michaely (2002) for a review of this literature.

17 Lintner (1956).
} 
$D \times \operatorname{GrossDP}_{i t-1}$, to examine whether the stability of gross dividend payout changes after the introduction of dividend imputation. Consistent with an increase in the volatility of gross dividend payout, we expect the positive relationship between current and lagged dividend payouts to be weaker under dividend imputation.

\subsection{Level of franked dividends}

The tax preference for the distribution of franked dividends and the retention of unfranked dividends established in the preceding section, suggests that with the introduction of dividend imputation, firms with a high proportion of income available as franked dividends will increase their gross dividend payout more than firms with a low proportion of income available as franked dividends.

In addition, the Australian corporate tax rate paid determines the level of franked dividends. That is, the higher the firm's effective tax rate, the higher the level of available of tax credit and the proportion of income available as franked dividends. Whereas firms with a low effective Australian tax rate will have a higher proportion of their distributable income as unfranked dividends. Hence, following the introduction of dividend imputation, firms with a history of a high effective Australian corporate tax rate, and an accumulation of franking tax credits, will increase their gross dividend payout more than firms with a low effective Australian corporate tax rate.

The cross-sectional relationship between gross dividend payout and effective corporate tax is analysed using the following regression equation:

$$
\operatorname{GrossDP}_{i t}=\hat{\beta}_{1} D+\hat{\beta}_{2} \mathrm{ETR}_{i t-1}+\hat{\beta}_{3} D \times \mathrm{ETR}_{i t-1}+\hat{\beta}_{4} W_{i j t}+\varepsilon_{i t}
$$

The dependent variable $\left(\mathrm{GrossDP}_{i t}\right)$, is the gross dividend payout for firm $i, \mathrm{ETR}_{i t-1}$ is firm $i$ 's effective corporate tax rate in period $t-1$, measured as the proportion of tax paid to pre tax income, $\frac{\text { tax paid }}{\text { pretax income }}$. We include an interaction effect between the imputation dummy variable and firm i's effective tax rate, $D \times \mathrm{ETR}_{i t-1}$, to examine the cross-sectional relationship between the firms's effective corporate tax rate and changes in dividend policy after the introduction of dividend imputation.

In addition to the effective corporate tax rate, we consider the level of franking, defining a franked dividend dummy, DF, taking a value of one if the dividend payment is franked and zero otherwise. The cross-sectional relationship between gross dividend payout and the level of franked dividends is analysed using the following regression equation:

$$
\operatorname{GrossDP}_{i t}=\hat{\beta}_{1} \mathrm{DF}_{t}+\hat{\beta}_{3} W_{i j t}+\varepsilon_{i t}
$$

\subsection{Dividend initiations}

The decision to initiate a dividend has been shown to present a strong signal to the market regarding future firm profitability (Lintner, 1956; Michaely et al., 1995). In considering whether to initiate a dividend stream a firm also considers its ability to continue the payments (Baker et al., 2002).

In addition to these factors the introduction of a dividend imputation system and the subsequent tax preference to distribute franked dividends will lead non-dividend paying firms with imputation credits to initiate. The implication is an increase in dividend initiations following the introduction of dividend imputation in 1987. Therefore, we hypothesise that, ceteris paribus, the frequency of dividend initiations will increase, following the introduction of dividend imputation.

Using a sample of dividend initiating firms, we examine changes in the propensity to initiate a dividend stream around the introduction of dividend imputation using the following logit regression equation:

$$
\text { Init }_{i t}=\hat{\beta}_{1} D+\hat{\beta}_{2} \mathrm{MB}_{i t}+\hat{\beta}_{3} \text { Profit }_{i t}+\varepsilon_{i t}
$$

Where the dependent variable $\left(\mathrm{Init}_{i t}\right)$, is a dummy variable taking a value of one if the firm initiates a dividend in period $t$ and zero otherwise. The existing literature (Baker and Wurgler, 2002) identifies an association between market-to-book (measured here as market value of equity over book value of equity), profitability and the propensity to initiate a dividend. Therefore these are included as control variables in the initiation regressions. 
Following from the previous section, we hypothesize that, ceteris paribus, subsequent to the introduction of dividend imputation, dividend initiations will be positively correlated with the firm's effective corporate tax rate and the level of franked dividends. We examine these cross-sectional relationships using the following logit regression equations:

$$
\begin{aligned}
& \text { Init }_{i t}=\hat{\beta}_{1} \mathrm{ETR}_{i t-1}+\hat{\beta}_{2} D \times \mathrm{ETR}_{i t-1}+\hat{\beta}_{3} \mathrm{MB}_{i t}+\hat{\beta}_{4} \text { Profit }_{i t}+\varepsilon_{i t} \\
& \text { Init }_{i t}=\hat{\beta}_{1} \mathrm{DF}_{i t}+\hat{\beta}_{2} \mathrm{MB}_{i t}+\hat{\beta}_{3} \text { Profit }_{i t}+\varepsilon_{i t}
\end{aligned}
$$

\subsection{Net dividend payout}

In determining the firm's total payout it must be recognised that management may pay a dividend and concurrently raise new equity. The tax preference for the distribution of franked dividends will result in firms increasing the use of external equity financing to compensate for the increased distribution of retained earnings. ${ }^{18}$ Dividend reinvestment plans allow shareholders to use all or part of their dividend to subscribe to new shares, at a discount this results in firms retaining cash for investment and shareholders receiving franking credits. The choice of reinvestment of the dividend or receipt of the cash is made by the investor and can be reversed at any time. We define the firm's net dividend payment to be the gross dividend payment less new equity issues, via dividend reinvestment plans, rights issues, public issues or private placements.

For all investors, the introduction of a dividend imputation tax system established a tax preferred dividend distribution policy, which has implications for the level and form of the firm's gross dividend payment. However, a consequent need to increase funding to replace the higher dividend payout suggests there may be a decrease in the level of the firm's net dividend payment. ${ }^{19}$

We hypothesise that for all firms, ceteris paribus, following the introduction of dividend imputation: the proportion of firms offering a dividend reinvestment plan (DRP), total dividend reinvestment plans and current dividend reinvestment plan, will increase. The direction of the change in net dividend payout is unclear, being determined by the demand for new equity capital.

The behaviour of net dividend payout and the utilisation of dividend reinvestment schemes around the introduction of dividend imputation are examined using regression Eq. (1), where the dependent variable ( $\left.\mathrm{DP}_{i t}\right)$ for firm $i$ is:

(i) net dividend payout in period $t$, [ net dividend payment $]$, and

(ii) DRP utilization in period $t$, a dummy variable taking a value of one if the firm has an operating dividend reinvestment plan in period $t$ and zero otherwise.

\section{Sample selection}

The sample period is from January 1982 to December 1997. It encompasses the period of change to the Australian tax regimes with the introduction of a dividend imputation system on 1 July 1987.

The initial sample consists of all firms selected from Compustat Global, which were incorporated in Australia, with a fiscal year end month up to and including June, and accounting data available over the full sample period. The initial sample consists of 306 firms totalling 3144 firm-years. We constrain the sample to comprise those firms that have observations in each sub period 1982 to 1986 and 1987 to 1997; however, for any one firm it is not necessary that data is available for all years in the sample. The sample comprises firms across all industry sectors. The sample is biased towards large publicly listed dividend paying firms, ${ }^{20}$ but is not unrepresentative of the Australian market. Data on regular and special dividends, dividend reinvestment plans, bonus share plans and share repurchases were hand collected from the Australian Stock Exchange weekly summary sheets. In any year in which the firm does not pay a dividend the dividend payment is set to zero. The final sample consists of 151 firms totalling 1628 firm-years.

Given the bias of this initial sample towards dividend paying firms, we collected a sample of dividend-initiating firms, constructed from all firms listed on the Australian Stock Exchange that initiated a dividend stream during the

\footnotetext{
18 Twite (2001) finds that the proportion of capital raised via new equity issues increased following the introduction of a dividend imputation system in Australia.

${ }^{19}$ See Allen and Michaely (2002) for a review of the determinants of the firm's net dividend payment.

${ }^{20}$ The sample includes only 17 firms that had never paid a dividend. In all cases these firms initiated a dividend during the sample period.
} 
Table 2

Summary statistics

\begin{tabular}{|c|c|c|c|c|c|c|}
\hline Variable & Mean & Median & Std dev & Min & Max & $N$ \\
\hline \multicolumn{7}{|l|}{ Panel A: dividend paying firms } \\
\hline Profitability & 0.062 & 0.054 & 0.042 & 0.001 & 0.228 & 1628 \\
\hline Operating risk & 0.026 & 0.013 & 0.048 & 0.000 & 0.562 & 1628 \\
\hline Tangible assets & 0.605 & 0.584 & 0.254 & 0.000 & 1.000 & 1628 \\
\hline Firm size & 6.286 & 6.284 & 1.472 & 2.274 & 10.630 & 1628 \\
\hline Market-to-book & 1.697 & 1.466 & 0.936 & 0.245 & 5.265 & 1628 \\
\hline Leverage & 0.244 & 0.233 & 0.185 & 0.000 & 0.967 & 1628 \\
\hline \multicolumn{7}{|l|}{ Panel B: dividend initiating firms } \\
\hline Profitability & 0.080 & 0.065 & 0.057 & 0.001 & 0.230 & 899 \\
\hline Operating risk & 0.061 & 0.028 & 0.096 & 0.001 & 0.583 & 899 \\
\hline Tangible assets & 0.335 & 0.263 & 0.288 & 0.000 & 1.000 & 899 \\
\hline Firm size & 4.370 & 4.227 & 1.535 & 0.984 & 8.141 & 899 \\
\hline Market-to-book & 1.598 & 1.180 & 1.214 & 0.255 & 5.277 & 899 \\
\hline Leverage & 0.189 & 0.123 & 0.206 & 0.000 & 0.913 & 899 \\
\hline \multicolumn{7}{|l|}{ Panel C: pooled sample } \\
\hline Gross dividend payout & 0.643 & 0.573 & 0.376 & 0.001 & 1.886 & 2527 \\
\hline Regular dividend payout & 0.620 & 0.567 & 0.335 & 0.001 & 1.670 & 2527 \\
\hline Non-regular dividend payout & 2.004 & 0.334 & 5.603 & 0.333 & 28.203 & 2527 \\
\hline Net dividend payout & 0.573 & 0.487 & 1.383 & -5.225 & 11.184 & 2527 \\
\hline Profitability & 0.067 & 0.056 & 0.046 & 0.001 & 0.230 & 2527 \\
\hline Operating risk & 0.035 & 0.016 & 0.065 & 0.000 & 0.583 & 2527 \\
\hline Tangible assets & 0.539 & 0.540 & 0.288 & 0.000 & 1.000 & 2527 \\
\hline Firm size & 5.825 & 5.828 & 1.697 & 0.984 & 10.630 & 2527 \\
\hline Market-to-book & 1.673 & 1.423 & 1.109 & 0.245 & 5.277 & 2527 \\
\hline Leverage & 0.231 & 0.213 & 0.192 & 0.000 & 0.967 & 2527 \\
\hline
\end{tabular}

This table presents summary statistics for our sample, which consists of dividend paying and initiating firms over the period 1982 through 1997 . The table presents the mean, median, standard deviation, minimum, maximum, and number of observations for each variable. Gross dividend payout, Regular dividend payout, Non-regular dividend payout and Net dividend payout are the ratios of gross dividend payments (sum of regular cash dividends, regular script dividends, bonus share plans, special cash dividends, special script dividends and off-market share repurchases.), regular dividend payments (sum of regular cash dividends and regular script dividends), non-regular dividend payments (sum of special cash dividends, special script dividends and off-market share repurchases) and net dividend payments (gross dividend payment less new equity issues, via dividend reinvestment plans, rights issues, public issues or private placements) to net income. Profitability is defined as net income over total assets, Operating risk as absolute value of the change in profitability from period $t-1$ to period $t$, Asset tangibility as fixed assets over total assets, Market-to-book as market value of equity over book value of equity and Leverage as total debt over market value of firm. Firm size is the natural logarithm of total assets. Panel A presents the sample of dividend paying firms, Panel B the sample of dividend initiating firms and Panel C the pooled sample.

sample period. The initial sample contained 806 initiations. We removed those that occurred within 12 months of listing date. The final sample of initiations is 144 firms totalling 899 firm-years. Accounting numbers were extracted from annual financial reports. From Table 2, we see that dividend-initiating firms are smaller, more profitable firms with less tangible assets and lower leverage than established dividend paying firms.

The pooled sample, combining both dividend paying and dividend initiating firms is 295 firms totalling 2527 firm-years.

As identified in Section 3, our tests include several firm variables. The existing empirical literature on dividend policy suggests an association between the firm's dividend payout and the following firm level variables. ${ }^{21}$ These $^{2}$ variables include profitability $\left[\frac{\mathrm{net} \text { income }}{\mathrm{total} \text { assets }}\right.$, operating risk [absolute value of change in profitability, period $t-1$ to period $t]$, asset tangibility [fixed assets $]$, the market-to-book ratio $\left[\frac{\text { market value of equity }}{\text { book value of equity }}\right]$ and leverage $\left[\frac{\text { total debt }}{\text { market value of firm }}\right]$.

We use firm size [natural logarithm of total assets] as a proxy for financial market access. Larger firms with better market access and external equity financing opportunities should be able to pay higher dividends. Hence, we expect a positive relationship between size and dividend payments.

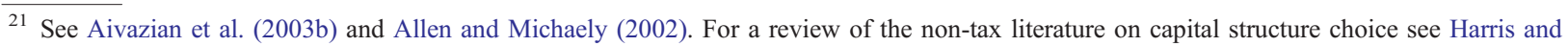
Raviv (1991).
} 
In addition to these variables, we include GDP growth [GDP growth], because high economic growth is generally associated with higher investment activity, financing demand and profitability, all associated with dividend payout levels. Further, we conjecture that firms considering commencing dividends are more likely to initiate in periods of high economic growth.

\section{Results}

\subsection{Summary statistics}

Table 2, which presents the summary statistics, shows that for the pooled sample, regular dividend payments represent $62.0 \%$ of net income on average. Gross dividends payments as a portion of net income have, as expected, a higher mean (64.3\%), while net dividends represent an average of $57.3 \%$ of net income, reflecting new capital raisings via equity issues or dividend reinvestment plans. Net income and fixed assets are on average $6.7 \%$ and $53.9 \%$ of total assets, respectively, while debt represents an average of $23.1 \%$ of the market value of capital.

Table 3 details the number of dividend payments by year for gross dividends, regular dividends, non-regular dividends, dividend reinvestment plans, bonus share plans, net dividends and dividend initiations. All companies with a fiscal year end prior to 1 July 1982 are classified as 1982 companies, while those with a fiscal year end subsequent to 1 July 1982 are classified as 1983 companies. Similarly for 1983 through 1997.

From Table 3 we observe that the number of firms offering dividend reinvestment plans increased after the introduction of dividend imputation in 1987. The difference in the means of the pre and post 1987 sub-periods is statistically significantly positive. The t-statistic is 6.40 (not reported). Likewise the use of special dividends, script dividends and off-market share repurchases all occur after 1987. This suggests the use of special dividends and share repurchases to manage the flow of imputation tax credits. There was a large increase in the number of firms paying nonregular dividends in 1989. This is consistent with firms catering to the increased demand for the distribution of imputation tax credits following the inclusion of pension funds in the imputation tax system in 1988.

Table 3 also reports a decline in the number of firms offering bonus share plans after 1989. The difference in the means of the pre and post 1987 sub-periods is statistically significantly negative ( $t$-statistic -2.22 not reported). At the same time

Table 3

Dividend frequency: 1982 to 1997

\begin{tabular}{|c|c|c|c|c|c|c|c|c|}
\hline Year & $\begin{array}{l}\text { Gross } \\
\text { dividend }\end{array}$ & $\begin{array}{l}\text { Regular } \\
\text { dividend }\end{array}$ & $\begin{array}{l}\text { Non-regular } \\
\text { dividend }\end{array}$ & $\begin{array}{l}\text { Dividend reinvestment } \\
\text { plan }\end{array}$ & $\begin{array}{l}\text { Bonus share } \\
\text { plan }\end{array}$ & $\begin{array}{l}\text { Net } \\
\text { dividend }\end{array}$ & $\begin{array}{l}\text { Dividend } \\
\text { initiations }\end{array}$ & $\begin{array}{l}\text { Number of } \\
\text { firms }\end{array}$ \\
\hline 1982 & 87 & 87 & 1 & 1 & 19 & & 2 & 110 \\
\hline 1983 & 84 & 84 & & 3 & 12 & 84 & 3 & 106 \\
\hline 1984 & 106 & 106 & & 7 & 28 & 106 & 3 & 134 \\
\hline 1985 & 112 & 112 & & 11 & 33 & 112 & 5 & 149 \\
\hline 1986 & 119 & 119 & & 12 & 23 & 119 & 11 & 173 \\
\hline 1987 & 134 & 134 & & 19 & 51 & 134 & 20 & 213 \\
\hline 1988 & 134 & 134 & 6 & 21 & 20 & 134 & 16 & 217 \\
\hline 1989 & 131 & 131 & 29 & 35 & 30 & 131 & 17 & 205 \\
\hline 1990 & 128 & 128 & 6 & 26 & 13 & 128 & 13 & 191 \\
\hline 1991 & 114 & 114 & 6 & 22 & 12 & 114 & 5 & 177 \\
\hline 1992 & 113 & 113 & & 23 & 13 & 113 & 7 & 173 \\
\hline 1993 & 101 & 101 & 2 & 26 & 16 & 101 & 10 & 159 \\
\hline 1994 & 83 & 83 & 5 & 26 & 13 & 83 & 10 & 143 \\
\hline 1995 & 84 & 84 & 3 & 15 & 12 & 84 & 10 & 139 \\
\hline 1996 & 86 & 86 & 3 & 14 & 12 & 86 & 6 & 144 \\
\hline 1997 & 85 & 85 & 6 & 10 & 11 & 85 & 8 & 134 \\
\hline
\end{tabular}

The table provides the number of dividend payments by year for gross dividends, regular dividends, non-regular dividends, script dividends, offmarket share repurchases, current dividend reinvestment plans bonus share plan, net dividends and dividend initiations over the sample period 1982 through 1997. Gross dividend payments are defined to be the sum of regular cash dividends, regular script dividends, bonus share plans, special cash dividends, special script dividends and off-market share repurchases. Regular dividend payments are defined to be the sum of regular cash dividends and regular script dividends. Non-regular dividend payments are defined to be the sum of special cash dividends, special script dividends and offmarket share repurchases. Dividend reinvestment plans allow shareholders to reinvest the dividend. Bonus share plans allow shareholders to renounce their right to the dividend in favor of a bonus issue. Net dividend payments are defined to be the gross dividend payment less new equity issues, via dividend reinvestment plans, rights issues, public issues or private placements. 
Table 4

Median dividend payout: 1982 to 1997

\begin{tabular}{|c|c|c|c|c|c|}
\hline Year & Gross dividend payout & Regular dividend payout & Non-regular dividend payout & Net dividend payout & Number of firms \\
\hline 1982 & 0.4373 & 0.4373 & -0.0052 & & 110 \\
\hline 1983 & 0.5230 & 0.5230 & & 0.4090 & 106 \\
\hline 1984 & 0.4715 & 0.4715 & & 0.3800 & 134 \\
\hline 1985 & 0.4666 & 0.4666 & & 0.2110 & 149 \\
\hline 1986 & 0.4610 & 0.4610 & & 0.2700 & 173 \\
\hline 1987 & 0.4570 & 0.4570 & & 0.0000 & 213 \\
\hline 1988 & 0.4770 & 0.4710 & 0.3890 & 0.3700 & 217 \\
\hline 1989 & 0.5420 & 0.5210 & 0.1317 & 0.4010 & 205 \\
\hline 1990 & 0.5481 & 0.5457 & 0.3090 & 0.4202 & 191 \\
\hline 1991 & 0.5542 & 0.5542 & 2.0100 & 0.4800 & 177 \\
\hline 1992 & 0.5560 & 0.5560 & & 0.4870 & 173 \\
\hline 1993 & 0.6070 & 0.5970 & 1.4480 & 0.5160 & 159 \\
\hline 1994 & 0.6040 & 0.6040 & 15.9000 & 0.5700 & 143 \\
\hline 1995 & 0.6400 & 0.6400 & 7.1900 & 0.5720 & 139 \\
\hline 1996 & 0.6760 & 0.6760 & 0.3378 & 0.6360 & 144 \\
\hline 1997 & 0.6950 & 0.6890 & 1.7000 & 0.6380 & 134 \\
\hline$\chi^{2}$-statistic-median & $27.033^{* * *}$ & $23.498^{* * *}$ & & & \\
\hline
\end{tabular}

*** Significant at the $1 \%$ level.

The table provides the median value for gross, regular, non-regular and net dividend over the sample period 1982 through 1997 . Dividend payout measures are defined as in Table 2. The Chi-square statistics compares the medians in the pre and post 1987 sub-periods.

there is an increase in the number of firms offering dividend reinvestment plans. The difference in the means of the pre and post 1987 sub-periods is statistically significantly positive ( $t$-statistic 2.33 not reported). This decline in bonus share plans can be attributed to differences in the taxation of dividend reinvestment and bonus share plans. Bonus share plans allow shareholders to renounce their right to the dividend in favor of a bonus issue. Hence, for tax purposes bonus share plans are a return of capital, subject to capital gains tax. While dividend reinvestment plans are treated as a dividend for taxation purposes, as if the cash dividend upon receipt by the shareholder was immediately applied to the purchase of new shares. However, following changes to the Australian taxation system in 1990, from the company's viewpoint they are equivalent with both giving rise to a reduction of the company's franking account with a loss of franking credits. ${ }^{22}$

We observe that the number of dividend initiations increase after the introduction of dividend imputation in 1987, with the number of dividend initiations increasing to 20 and 16 in 1987 and 1988, respectively. Overall, the number of dividend initiations was 24 in the earlier period, increasing to 122 after the introduction of dividend imputation.

Table 4 sets out the median values by year of gross dividend payout, regular dividend payout, non-regular dividend payout, script dividend proportion and net dividend payout.

In general, post 1987, all dividend payouts rise consistent with the preference for the distribution of franked dividends. From Table 4, the difference in the median payouts of both gross and regular dividends between the pre and post 1987 sub-periods are statistically significantly positive. In addition, both the mean and variance increase following the introduction of dividend imputation. For both gross and regular dividends, the mean payouts ( $t$-statistic 4.69 and 4.24 respectively) and the variance of payouts ( $F$-statistic 0.681 and 0.723 respectively) are significantly different. It is noteworthy that while rising after 1987, as hypothesized, the level of non-regular dividend payouts are variable. Taken in conjunction with the decline in active dividend reinvestment plans this is suggestive of a decline in funding demand. This explanation is further supported by the relative rise in net dividends over the same period implying that firms are continuing to meet the requirement for dividend payout but have sufficient internal funds to meet financing requirements. In summary, regular dividends still represent the dominate payments mechanism post 1987.

\subsection{Dividend policy and dividend imputation}

Table 5 presents a correlation matrix for our data, and some univariate evidence consistent with our hypotheses gross, regular, non-regular and net dividend payouts together with dividend reinvestment plan utilization are positively

$\overline{22}$ See Murray and Skully (2003) for a more detailed discussion of the tax treatment of dividend reinvestment and bonus plans. 
Table 5

Correlation matrix

\begin{tabular}{|c|c|c|c|c|c|c|c|c|c|c|c|c|c|c|c|}
\hline Variable & & {$[1]$} & {$[2]$} & {$[3]$} & [4] & {$[5]$} & {$[6]$} & {$[7]$} & [8] & [9] & {$[10]$} & {$[11]$} & {$[12]$} & {$[13]$} & [14] \\
\hline $\begin{array}{l}\text { Gross } \\
\text { dividend } \\
\text { payout }\end{array}$ & {$[1]$} & 1.000 & & & & & & & & & & & & & \\
\hline $\begin{array}{l}\text { Regular } \\
\text { dividend } \\
\text { payout }\end{array}$ & {$[2]$} & 0.984 & 1.000 & & & & & & & & & & & & \\
\hline $\begin{array}{l}\text { Non-regular } \\
\text { dividend } \\
\text { payout }\end{array}$ & {$[3]$} & 0.915 & 0.752 & 1.000 & & & & & & & & & & & \\
\hline $\begin{array}{l}\text { Net } \\
\quad \text { dividend } \\
\text { payout }\end{array}$ & [4] & 0.586 & 0.547 & 0.856 & 1.000 & & & & & & & & & & \\
\hline $\begin{array}{l}\text { DRP } \\
\text { utilization }\end{array}$ & {$[5]$} & 0.052 & 0.046 & -0.053 & 0.059 & 1.000 & & & & & & & & & \\
\hline $\begin{array}{l}\text { Dividend } \\
\text { imputation }\end{array}$ & {$[6]$} & 0.072 & 0.061 & 0.061 & 0.091 & 0.112 & 1.000 & & & & & & & & \\
\hline Effective tax & {$[7]$} & 0.009 & 0.008 & -0.079 & 0.002 & 0.023 & -0.025 & 1.000 & & & & & & & \\
\hline $\begin{array}{l}\text { Franked } \\
\text { dividend }\end{array}$ & [8] & 0.094 & 0.083 & -0.017 & 0.092 & 0.258 & 0.388 & 0.043 & 1.000 & & & & & & \\
\hline GDP growth & [9] & -0.048 & -0.056 & -0.245 & -0.005 & 0.016 & 0.049 & 0.023 & 0.006 & 1.000 & & & & & \\
\hline Profitability & [10] & -0.214 & -0.221 & -0.192 & 0.059 & 0.074 & -0.026 & 0.016 & 0.117 & 0.078 & 1.000 & & & & \\
\hline $\begin{array}{l}\text { Operating } \\
\text { risk }\end{array}$ & [11] & -0.106 & -0.109 & -0.002 & -0.066 & -0.108 & 0.074 & -0.018 & -0.101 & -0.078 & -0.454 & 1.000 & & & \\
\hline $\begin{array}{c}\text { Tangible } \\
\text { assets }\end{array}$ & [12] & 0.196 & 0.199 & 0.141 & 0.064 & 0.056 & 0.060 & 0.018 & 0.160 & -0.053 & 0.081 & -0.103 & 1.000 & & \\
\hline Firm size & [13] & 0.056 & 0.066 & 0.172 & 0.047 & 0.253 & 0.117 & 0.056 & 0.268 & 0.015 & 0.211 & -0.379 & 0.334 & 1.000 & \\
\hline $\begin{array}{l}\text { Market-to- } \\
\text { book }\end{array}$ & [14] & 0.041 & 0.043 & 0.143 & 0.021 & 0.026 & -0.064 & 0.032 & 0.081 & 0.061 & 0.173 & 0.028 & 0.130 & -0.018 & 1.000 \\
\hline Leverage & [15] & -0.066 & -0.066 & -0.127 & -0.058 & 0.004 & 0.024 & -0.014 & -0.035 & -0.068 & -0.192 & -0.008 & 0.022 & 0.296 & -0.391 \\
\hline $\begin{array}{l}\text { Dividend } \\
\text { initiation }\end{array}$ & [16] & & & & & & 0.012 & 0.019 & 0.026 & 0.141 & 0.005 & & & & -0.001 \\
\hline
\end{tabular}

This table presents the correlation matrix for our sample, which consists of dividend paying and initiating firms over the period 1982 through 1997. Pearson correlations for each pair of independent variables are presented. DRP utilization is a dummy variable taking a value of one if the firm has an operating dividend reinvestment plan and zero otherwise. Dividend imputation is a dummy variable taking a value of one under an imputation system and zero otherwise. Dividend initiation is a dummy variable taking a value of one if the firm initiates a dividend and zero otherwise. Effective tax is defined as tax paid over pre tax income. Franked dividend is a dummy variable taking a value of one if the dividend payment is franked and zero otherwise. Economic growth is measured as growth in GDP. Other variables are as defined in Table 2.

correlated with the introduction of dividend imputation. In addition, gross dividend payout is positively correlated with the effective corporate tax rate and the level of franked dividends. Finally, dividend initiations are positively correlated with the introduction of dividend imputation, the effective corporate tax rate and the level of franked dividends. Table 5 also shows that none of our independent variables exhibit alarming degrees of (pairwise) multicollinearity.

\subsection{Dividend paying firms}

Using the pooled sample, we estimate Eq. (1) for each dependent variable over the full sample period. The years 1987 and 1988 are excluded to allow for changeover effects to diminish and the impact of pension fund taxation to take effect. ${ }^{23}$ With the exception of net dividend, dividend payout ratios are transformed by natural logarithm to mitigate the effect of leverage points. Net dividend payout ratios are winsorized at the $1 \%$ level. ${ }^{24}$ The regression of dividend reinvestment plan utilization is performed using the logit method.

\footnotetext{
23 Our results are robust to the inclusion of 1987 and 1988.

${ }^{24}$ To reduce the impact of leverage points we winsorize this variable at the $1 \%$ level in each tail of the distribution. Even though our other dependent variables are transformed by the natural logarithm, we choose to winsorize this variable to preserve negative values.
} 
Table 6

Pooled firm-level regressions of dividend payouts

\begin{tabular}{|c|c|c|c|c|c|c|}
\hline \multirow{2}{*}{$\begin{array}{l}\text { Dependent variable } \\
\text { Independent variable }\end{array}$} & \multirow{2}{*}{$\begin{array}{l}\text { Gross } \\
\text { dividend } \\
\text { payout }\end{array}$} & \multirow{2}{*}{$\begin{array}{l}\text { Regular } \\
\text { dividend } \\
\text { payout }\end{array}$} & \multirow{2}{*}{$\begin{array}{l}\text { Net } \\
\text { dividend } \\
\text { payout }\end{array}$} & \multirow{2}{*}{$\begin{array}{l}\text { DRP } \\
\text { utilization }\end{array}$} & \multicolumn{2}{|c|}{ Gross dividend payout } \\
\hline & & & & & & \\
\hline Dividend imputation & $\begin{array}{l}0.1520 \\
(2.59)^{* * *}\end{array}$ & $\begin{array}{l}0.1246 \\
(2.15)^{* *}\end{array}$ & $\begin{array}{l}0.3095 \\
(3.37)^{* * *}\end{array}$ & $\begin{array}{l}0.3832 \\
(2.17)^{* *}\end{array}$ & & \\
\hline Effective tax & & & & & $\begin{array}{l}-0.3608 \\
(-2.52)^{* *}\end{array}$ & \\
\hline Interaction - tax and imputation & & & & & $\begin{array}{l}0.3574 \\
(2.50)^{* *}\end{array}$ & \\
\hline Franked dividend & & & & & & $\begin{array}{l}0.1267 \\
(2.17)^{* *}\end{array}$ \\
\hline GDP growth & $\begin{array}{l}-0.0072 \\
(-0.82)\end{array}$ & $\begin{array}{l}-0.0090 \\
(-1.06)\end{array}$ & $\begin{array}{l}-0.0086 \\
(-0.57)\end{array}$ & $\begin{array}{l}-0.0086 \\
(-0.26)\end{array}$ & $\begin{array}{l}-0.0052 \\
(-0.66)\end{array}$ & $\begin{array}{l}-0.0048 \\
(-0.57)\end{array}$ \\
\hline Profitability & $\begin{array}{l}-7.3865 \\
(-6.25)^{* * *}\end{array}$ & $\begin{array}{l}-7.4581 \\
(-6.31)^{* * *}\end{array}$ & $\begin{array}{l}0.4756 \\
(2.21)^{* *}\end{array}$ & $\begin{array}{l}-0.1254 \\
(-0.24)\end{array}$ & $\begin{array}{l}-7.2855 \\
(-6.25)^{* * *}\end{array}$ & $\begin{array}{l}-7.3250 \\
(-6.25)^{* * *}\end{array}$ \\
\hline Operating risk & $\begin{array}{l}0.1802 \\
(0.63)\end{array}$ & $\begin{array}{l}0.2233 \\
(0.71)\end{array}$ & $\begin{array}{l}-0.0359 \\
(-1.96)^{* *}\end{array}$ & $\begin{array}{l}-0.0406 \\
(-0.09)\end{array}$ & $\begin{array}{l}0.2675 \\
(0.67)\end{array}$ & $\begin{array}{l}0.1780 \\
(0.63)\end{array}$ \\
\hline Tangible assets & $\begin{array}{l}0.3413 \\
(2.81)^{* * *}\end{array}$ & $\begin{array}{l}0.3242 \\
(2.70)^{* * *}\end{array}$ & $\begin{array}{l}0.1771 \\
(1.34)\end{array}$ & $\begin{array}{l}-0.5359 \\
(-2.28)^{* *}\end{array}$ & $\begin{array}{l}0.3539 \\
(2.93)^{* * *}\end{array}$ & $\begin{array}{l}0.3569 \\
(2.95)^{* * *}\end{array}$ \\
\hline Firm size & $\begin{array}{l}-0.0489 \\
(-2.05)^{* *}\end{array}$ & $\begin{array}{l}-0.0452 \\
(-1.90)^{*}\end{array}$ & $\begin{array}{l}0.0052 \\
(0.26)\end{array}$ & $\begin{array}{l}0.2945 \\
(3.98)^{* * *}\end{array}$ & $\begin{array}{l}-0.0530 \\
(-2.29)^{* *}\end{array}$ & $\begin{array}{l}-0.0430 \\
(-1.71)^{*}\end{array}$ \\
\hline Market-to-book & $\begin{array}{l}0.0841 \\
(2.52)^{* * *}\end{array}$ & $\begin{array}{l}0.0887 \\
(2.69)^{* * *}\end{array}$ & $\begin{array}{l}-0.0090 \\
(-0.33)\end{array}$ & $\begin{array}{l}0.0147 \\
(0.22)\end{array}$ & $\begin{array}{l}0.0957 \\
(2.82)^{* * * *}\end{array}$ & $\begin{array}{l}0.0767 \\
(2.30)^{* *}\end{array}$ \\
\hline Leverage & $\begin{array}{l}-0.6520 \\
(-2.85)^{* * *}\end{array}$ & $\begin{array}{l}-0.6439 \\
(-2.87)^{* * *}\end{array}$ & $\begin{array}{l}-0.5213 \\
(-3.07)^{* * *}\end{array}$ & $\begin{array}{l}-0.6583 \\
(-1.48)\end{array}$ & $\begin{array}{l}-0.5966 \\
(-2.96)^{* * *}\end{array}$ & $\begin{array}{l}-0.6689 \\
(-2.94)^{* * *}\end{array}$ \\
\hline Observations & 295 & 295 & 295 & 151 & 295 & 295 \\
\hline Adjusted $R^{2}$ & 0.2119 & 0.2160 & 0.0382 & 0.1587 & 0.2209 & 0.2108 \\
\hline
\end{tabular}

$*, * *$, and $* * *$, significant at the 10,5 and 1 percent level, respectively.

This table presents regressions of our measures of gross, regular and net dividend payouts; and DRP utilization on an imputation dummy variable, plus the firm's effective corporate tax rate, an interaction between the effective tax rate and dividend imputation, a franked dividend dummy variable and firm characteristic variables — profitability, operating risk, tangible assets, size, market-to-book and leverage. Variables are as defined in Tables 2 and 5. With the exception of net dividend, dividend payout ratios are transformed by natural log. Net dividend payout ratios are winsorized at the $1 \%$ level. The regression of dividend reinvestment plan utilization is performed using the logit method. The years 1987 and 1988 are excluded to allow for changeover effects to diminish and the impact of pension fund taxation to take effect. Standard errors are robust to clustering within firms over time. $t$-statistics are in parentheses. All regressions include dummy variables for industry two-digit SIC codes (coefficients not reported). The table also reports the number of separate firms, and the $R^{2}$ for each regression.

For these regressions, and all of our subsequent regressions, we control for industry effects by including dummy variables for each industry using two-digit SIC codes (coefficients on these are not reported), and therefore, do not present intercept coefficients. In addition, we calculate standard errors that are robust to clustering within firms over time. Table 6 presents the results of these regressions.

Consistent with the relative attractiveness of all forms of dividend payments to domestic investors, we find that gross, regular and net dividend payout ratios and the use of dividend reinvestment plans increased subsequent to the introduction of dividend imputation. By implication, even after allowing for new equity issues (via dividend reinvestment plans, rights issues, public issues or private placements) the introduction of dividend imputation raises dividend payouts. ${ }^{25}$

We also examine differences in firm responses to the introduction of dividend imputation using Eqs. (3) and (4). Consistent with our expectations we find that the higher the level of available of franking tax credit the higher the firm's

\footnotetext{
${ }^{25}$ Our results may be influenced by other changes to the Australian taxation system that occurred during the sample period, particularly, the introduction of a capital gains tax in 1985 and the taxation of pension funds that commenced in 1988. In order to mitigate this potential effect, we include two dummy variables that take a value of one subsequent to the commencement of capital gains tax and pension fund taxation, respectively. Our results are robust to these changes. For example, over the full sample including 1987 and 1988, the estimated coefficient for the dividend imputation dummy is 0.1405 , significant at the $5 \%$ level, with the inclusion of capital gains tax and pension fund taxation dummies in the gross dividend regression. The estimated coefficients for both the capital gains tax and pension fun taxation dummies are significant at the $10 \%$ level and consistent with the sign of the predicted tax incentives, -0.0980 and 0.0961 , respectively.
} 
Table 7

Alternative tax regime pooled firm-level regressions of dividend payout ratios

\begin{tabular}{|c|c|c|c|c|c|c|c|c|c|}
\hline \multirow{2}{*}{$\begin{array}{l}\text { Dependent/ } \\
\text { independent } \\
\text { variables }\end{array}$} & \multicolumn{4}{|c|}{ Pre 1987 sub-period - Classical tax system } & \multicolumn{4}{|c|}{ Post 1988 sub-period — Dividend imputation tax system } & \multirow{2}{*}{$\begin{array}{l}\text { Gross } \\
\text { dividend } \\
F \text { statistic }\end{array}$} \\
\hline & $\begin{array}{l}\text { Gross } \\
\text { dividend } \\
\text { payout }\end{array}$ & $\begin{array}{l}\text { Regular } \\
\text { dividend } \\
\text { payout }\end{array}$ & $\begin{array}{l}\text { DRP } \\
\text { utilization }\end{array}$ & $\begin{array}{l}\text { Net } \\
\text { dividend } \\
\text { payout }\end{array}$ & $\begin{array}{l}\text { Gross } \\
\text { dividend } \\
\text { payout }\end{array}$ & $\begin{array}{l}\text { Regular } \\
\text { dividend } \\
\text { payout }\end{array}$ & $\begin{array}{l}\text { DRP } \\
\text { utilization }\end{array}$ & $\begin{array}{l}\text { Net } \\
\text { dividend } \\
\text { payout }\end{array}$ & \\
\hline GDP growth & $\begin{array}{l}-0.0138 \\
(-1.40)\end{array}$ & $\begin{array}{l}-0.0139 \\
(-1.41)\end{array}$ & $\begin{array}{l}0.0895 \\
(1.38)\end{array}$ & $\begin{array}{l}-0.0228 \\
(-0.92)\end{array}$ & $\begin{array}{l}0.0042 \\
(0.26)\end{array}$ & $\begin{array}{l}-0.0024 \\
(-0.16)\end{array}$ & $\begin{array}{l}0.0278 \\
(0.50)\end{array}$ & $\begin{array}{l}0.0078 \\
(0.36)\end{array}$ & \\
\hline Profitability & $\begin{array}{l}-11.5469 \\
(-3.36)^{* * *}\end{array}$ & $\begin{array}{l}-11.4345 \\
(-3.32)^{* * *}\end{array}$ & $\begin{array}{l}-19.4815 \\
(-3.78)^{* * *}\end{array}$ & $\begin{array}{l}-0.3758 \\
(-0.65)\end{array}$ & $\begin{array}{l}-7.7831 \\
(-6.61)^{* * *}\end{array}$ & $\begin{array}{l}-7.8730 \\
(-6.60)^{* * *}\end{array}$ & $\begin{array}{l}1.1684 \\
(0.92)\end{array}$ & $\begin{array}{l}0.6150 \\
(2.01)^{* *}\end{array}$ & $(8.81)^{* * *}$ \\
\hline $\begin{array}{l}\text { Operating } \\
\text { risk }\end{array}$ & 0.8990 & 0.9277 & $\begin{array}{l}-14.5331 \\
(-1.48)\end{array}$ & $\begin{array}{l}-0.9481 \\
(-1.04)\end{array}$ & $\begin{array}{l}-0.1089 \\
(-0.11)\end{array}$ & $\begin{array}{l}-0.0491 \\
(-0.04)\end{array}$ & $\begin{array}{l}-0.7708 \\
(-0.52)\end{array}$ & $\begin{array}{l}-0.6831 \\
(-1.57)\end{array}$ & $(1.68)$ \\
\hline $\begin{array}{c}\text { Tangible } \\
\text { assets }\end{array}$ & $\begin{array}{l}-0.2615 \\
(-0.79)\end{array}$ & $\begin{array}{l}-0.2465 \\
(-0.75)\end{array}$ & 1.9686 & 0.3780 & 0.2485 & $\begin{array}{l}0.2554 \\
(1.97)^{* *}\end{array}$ & $\begin{array}{l}-1.2462 \\
(-2.74)^{* * *}\end{array}$ & $\begin{array}{l}0.0581 \\
(0.42)\end{array}$ & $(0.27)$ \\
\hline Firm size & $\begin{array}{l}0.0085 \\
(0.10)\end{array}$ & $\begin{array}{l}0.0035 \\
(0.04)\end{array}$ & $\begin{array}{l}-0.9295 \\
(-1.70)^{*}\end{array}$ & $\begin{array}{l}-0.1406 \\
(-1.52)\end{array}$ & $\begin{array}{l}0.1484 \\
(3.68)^{* * *}\end{array}$ & $\begin{array}{l}0.1554 \\
(3.93)^{* * *}\end{array}$ & $\begin{array}{l}0.0967 \\
(0.66)\end{array}$ & $\begin{array}{l}0.0326 \\
(0.96)\end{array}$ & $(1.09)$ \\
\hline $\begin{array}{l}\text { Market-to- } \\
\text { book }\end{array}$ & $\begin{array}{l}-0.0639 \\
(-0.96)\end{array}$ & $\begin{array}{l}-0.0654 \\
(-0.98)\end{array}$ & $\begin{array}{l}1.4667 \\
(3.00)^{* * *}\end{array}$ & $\begin{array}{l}-0.0583 \\
(-1.13)\end{array}$ & $\begin{array}{l}-0.0968 \\
(-3.01)^{* * *}\end{array}$ & $\begin{array}{l}-0.0865 \\
(-2.73)^{* * *}\end{array}$ & $\begin{array}{l}0.3887 \\
(3.19)^{* * *}\end{array}$ & $\begin{array}{l}-0.0248 \\
(-1.00)\end{array}$ & $(0.06)$ \\
\hline Leverage & $\begin{array}{l}-1.0168 \\
(-2.34)^{* *}\end{array}$ & $\begin{array}{l}-1.0003 \\
(-2.30)^{* *}\end{array}$ & $\begin{array}{l}-4.2165 \\
(-2.09)^{* *}\end{array}$ & $\begin{array}{l}0.0435 \\
(0.10)\end{array}$ & $\begin{array}{l}-0.6170 \\
(-2.05)^{* * *}\end{array}$ & $\begin{array}{l}-0.6481 \\
(-2.20)^{* *}\end{array}$ & $\begin{array}{l}-1.4900 \\
(-2.01)^{* *}\end{array}$ & $\begin{array}{l}-0.4945 \\
(-2.56)^{* *}\end{array}$ & $(1.90)$ \\
\hline Observations & 125 & 125 & 125 & 125 & 215 & 215 & 215 & 215 & \\
\hline $\begin{array}{l}\text { Adjusted R- } \\
\text { square }\end{array}$ & 0.3735 & 0.3691 & 0.3941 & 0.0324 & 0.2429 & 0.2566 & 0.2179 & 0.0705 & \\
\hline
\end{tabular}

$*, * *$, and $* * *$, significant at the 10,5 and 1 percent level, respectively.

For each of the sub-periods - pre 1987(classical tax system) and post 1988 (dividend imputation tax system), this table presents regressions of our measures of gross, regular, non-regular and net dividend payouts; and DRP utilization on GDP growth and firm characteristic variables - profitability, operating risk, tangible assets, size, market-to-book and leverage. Variables are as defined in Tables 2 and 3. $t$-statistics are in parentheses. All regressions include dummy variables for industry two-digit SIC codes (coefficients not reported). The table also reports the number of separate firms, and the $R^{2}$ for each regression. The $F$ statistics compare the coefficients on firm level characteristics between the pre and post 1987 sub-periods.

gross dividend payout. In particular, we find that both firms with a high effective Australian corporate tax rate or a high proportion of income available as franked dividends have higher gross dividend payouts. ${ }^{26}$

Overall we find evidence to support the Pecking Order Hypothesis (Myers and Majluf, 1984), a negative association with leverage and a positive association with tangible assets. All these findings are consistent with the considerable literature in the area. Likewise the utilisation of dividend reinvestment plans is associated with firm size as would be expected since large growing firms use more cash for investment opportunities.

\subsection{Alternative tax regimes}

Following from Table 6, we re-estimate Eq. (1), excluding the dividend imputation tax system dummy, for gross, regular, net dividend payout ratios, together with dividend reinvestment plan utilization, for each of the sub-periods, 1982 to 1987 (classical tax system) and 1989 to 1997 (dividend imputation tax system) (see Table 7).

With respect to gross, regular and net dividend payout ratios, while the sign is consistent with the full sample period, the sub-period results are weaker.

Overall, the coefficient and sign on firm characteristics are not statistically significantly different across the subperiods with respect to gross dividend payout. This is suggestive of stability in the association between firm characteristics and dividend payout measures across alternative tax systems.

\footnotetext{
${ }^{26}$ Our results are robust to the substitution of net dividend payout for gross dividend payout.
} 
Table 8

Stability of gross dividend payout

\begin{tabular}{|c|c|}
\hline & Gross dividend \\
\hline Profitability & $\begin{array}{l}-1.2580 \\
(-2.21)^{* *}\end{array}$ \\
\hline Lagged gross dividend payout & $\begin{array}{l}0.4352 \\
(5.16)^{* * *}\end{array}$ \\
\hline Interaction — lagged gross dividend payout and imputation & $\begin{array}{l}-0.1667 \\
(-2.20)^{* *}\end{array}$ \\
\hline Observations & 295 \\
\hline Adjusted $R^{2}$ & 0.1335 \\
\hline
\end{tabular}

**, and $* * *$, significant at the 5 and 1 percent level, respectively.

This table presents the regression of our measures of gross dividend payout on profitability, lagged gross dividend payout and an interaction effect between the imputation dummy variable and firm lagged gross dividend payout. Variables are as defined in Tables 2 and 5 . The years 1987 and 1988 are excluded to allow for changeover effects to diminish and the impact of pension fund taxation to take effect. $t$-statistics are in parentheses. The table also reports the number of separate firms, and the $R^{2}$.

\subsection{Dividend payout stability}

We examine the impact of dividend imputation on the stability of gross dividend payout using the regression Eq. (2)where we include an interaction between the firm's lagged gross dividend payout (lagged one period) and the introduction of dividend imputation. We estimate Eq. (2) over the full sample period. The years 1987 and 1988 are excluded to allow for changeover effects to diminish and the impact of pension fund taxation to take effect. Table 8 presents the results of these regressions.

The results indicate that lagged gross dividend payout is positively associated with current gross dividend payout. However, with the introduction of dividend imputation, lagged gross dividend payout is negatively related to current gross dividend payout. This result is consistent with increased volatility in gross dividend payout under a dividend imputation tax system as a consequence of volatility in the level of tax credits available for distribution.

\subsection{Dividend initiations}

We expect that dividend initiating firms will have higher profitability and lower market-to-book ratio than nondividend paying firms, with the relationship weaker under dividend imputation.

We examine the impact of dividend imputation on dividend initiations using the logit regression Eqs. (5), (6) and (7). We estimate these equations over the full sample period. The years 1987 and 1988 are excluded to allow for changeover effects to diminish and the impact of pension fund taxation to take effect. Table 9 presents the results of this regression.

Consistent with the relative attractiveness of all forms of dividend payments to domestic investors, we find that dividend initiations increased subsequent to the introduction of dividend imputation. By implication, even after allowing for firm characteristics and high economic growth the introduction of dividend imputation raises the frequency of dividend initiations.

Contrary to expectations, we find no association between dividend initiation and the firm's effective tax rate following the introduction of dividend imputation. However, we find that firms with a high proportion of income available as franked dividends are more likely to initiate a dividend.

At the firm level we find profitable firms are more likely to initiate dividends. However, there is no association between dividend initiation and the firm's market-to-book ratio.

As expected dividend initiations are more likely under periods of high economic growth.

\section{Conclusion}

The introduction of a dividend imputation tax system to Australia represents a significant change to the tax framework. To the extent that tax incentives influence the payment of dividends, changes to the tax framework which alter the balance between dividend payment and retention will lead to a change in corporate dividend policy. This paper examines the changes in corporate dividend policy around the introduction of a dividend imputation tax system and highlights dividend policy sensitivity to major tax changes. 
Table 9

Dividend initiations

\begin{tabular}{|c|c|c|c|}
\hline Dependent/independent variable & Dividend initiation & & \\
\hline Dividend imputation & $\begin{array}{l}0.9719 \\
(3.33)^{* * *}\end{array}$ & & \\
\hline Effective tax & & $\begin{array}{l}-0.2202 \\
(-0.81)\end{array}$ & \\
\hline Interaction - tax and imputation & & $\begin{array}{l}0.3398 \\
(0.79)\end{array}$ & \\
\hline Franked dividend & & & $\begin{array}{l}0.9968 \\
(2.82)^{* * *}\end{array}$ \\
\hline GDP growth & $\begin{array}{l}0.3564 \\
(9.04)^{* * * *}\end{array}$ & $\begin{array}{l}0.3003 \\
(9.21)^{* * *}\end{array}$ & $\begin{array}{l}0.2968 \\
(9.04)^{* * *}\end{array}$ \\
\hline Profitability & $\begin{array}{l}3.5828 \\
(2.93)^{* * *}\end{array}$ & $\begin{array}{l}3.8031 \\
(3.00)^{* * *}\end{array}$ & $\begin{array}{l}3.2125 \\
(2.79)^{* * *}\end{array}$ \\
\hline Market-to-book & $\begin{array}{l}-0.0002 \\
(-0.25)\end{array}$ & $\begin{array}{l}-0.0002 \\
(-0.32)\end{array}$ & $\begin{array}{l}-0.0004 \\
(-0.55)\end{array}$ \\
\hline Observations & 157 & 157 & 157 \\
\hline Adjusted $R^{2}$ & 0.1186 & 0.1021 & 0.1109 \\
\hline
\end{tabular}

*** Significant at the $1 \%$ level.

This table presents the logit regression of our measure of dividend initiations on a dividend imputation dummy, plus GDP growth, the firm's effective tax rate, an interaction between the effective tax rate and dividend imputation, the firm's profitability and market-to-book. Variables are as defined in Tables 2 and 5. Dummy variables for industry two-digit SIC codes are included (coefficients not reported). The years 1987 and 1988 are excluded to allow for changeover effects to diminish and the impact of pension fund taxation to take effect. Standard errors are robust to clustering within firms over time. $t$-statistics are in parentheses. The table also reports the number of separate firms, and the $R^{2}$.

Overall, the paper offers consistent evidence to support the role of tax determinants in dividend policy for both firms and investors. The paper argues that in general, with the introduction of dividend imputation the firm has an incentive to initiate dividends, raise existing dividend payouts and change the form in which the dividend is paid, increasing the use of script dividends and share repurchases. Where the incentive to change dividend policy varies across firms conditioned on the level of available tax credits.

Consistent with the tax preference for the distribution of franked credits, the results reveal that dividend initiations, all dividend payout measures-gross, regular and net dividend payout ratios-and the use of dividend reinvestment plans increased subsequent to the introduction of dividend imputation. Interestingly, even after allowing for new equity issues, the introduction of dividend imputation raises dividend payouts. Similarly, we find that the volatility of gross dividend payout increased under dividend imputation.

We also find that the higher the level of available of franking tax credit the higher the firm's gross dividend payout and the more likely the firm is to initiate a dividend. In particular, firms with a high effective Australian corporate tax rate or a high proportion of income available as franked dividends have higher gross dividend payouts. Likewise, that firms with a high proportion of income available as franked dividends are more likely to initiate a dividend.

Finally, we find that the association between firm characteristics and dividend payout measures is stationary across alternative tax systems.

\section{References}

Aivazian, V., Booth, L., Cleary, S., 2003a. Dividend policy and the organisation of capital markets. Journal of Multinational Financial Management $13,101-121$.

Aivazian, V., Booth, L., Cleary, S., 2003b. Do emerging market firms follow different dividend policies than firms in the U.S: evidence from 8 emerging markets. Journal of Financial Research 26, 371-387.

Allen, F., Michaely, R., 2002. Payout policy. In: Constantinides, G., Harris, M., Stulz, R. (Eds.), North-Holland Handbooks of Economics. NorthHolland, Amsterdam, pp. 337-429.

Baker, M., Wurgler, J., 2002. Appearing and disappearing dividends: the link to catering incentives. Journal of Financial Economics 73 (2), $271-288$.

Baker, H.K., Powell, G.E., Veit, E.T., 2002. Revisiting managerial perspectives on dividend policy. Journal of Economics and Finance 26 (3), 267-283.

Black, F., 1976. The dividend puzzle. Journal of Portfolio Management 2, 5-8. 
Chan, K., McColough, D., Skully, M., 1995. Australian dividend reinvestment plans. Global Finance Journal 6, 79-99.

Grullon, G., Michaely, R., 2002. Dividends, share repurchases, and the substitution hypothesis. Journal of Finance 57, $1649-1684$.

Harris, M., Raviv, A., 1991. The theory of capital structure. Journal of Finance 46, 297-355.

Khoury, N., Smith, K., 1977. Dividend policy and the capital gains tax in Canada. Journal of Business Administration 11, 19-37.

Lintner, J., 1956. Distribution of incomes of corporations among dividends, retained earnings and taxes. American Economic Review 46, 97-113.

Michaely, R., 1991. Ex-dividend stock price behavior: the case of the 1986 Tax Reform Act. Journal of Finance 46, 845-860.

Michaely, R., Thaler, R., Womack, K., 1995. Price reactions to dividend initiations and omissions: overreaction or drift? Journal of Finance 50, $573-608$.

Miller, M.H., Modigliani, F., 1961. Dividend policy growth and the valuation of shares. Journal of Business 34, 411-433.

Miller, M.H., Scholes, M., 1978. Dividends and taxes. Journal of Financial Economics 6, 333-364.

Murray, J., Skully, M., 2003. Dividends, reinvestment and bonus shares: the shareholders' choice. Monash University working paper.

Myers, S.C., Majluf, N.S., 1984. Corporate financing and investment decisions when firms have information that investors do not have. Journal of Financial Economics 13, 187-221.

Partington, G., 1984. Dividend policy and target payout ratios. Accounting and Finance 24, 63-74.

Poterba, J.M., Summers, L., 1984. New evidence that taxes affect the valuation of dividends. Journal of Finance 39, $1397-1415$.

Smith, C.W., Watts, R.L., 1992. The investment opportunity set and corporate financing dividend, and compensation policies. Journal of Financial Economics 32, 263-292.

Twite, G., 2001. Capital structure choices and taxes: evidence from the Australian dividend imputation tax system. International Review of Finance 2, 217-234. 